Univerzitet u Beogradu
Poljoprivredni fakultet
Institut za poljoprivrednu tehniku
Naučni časopis
POLJOPRIVREDNA TEHNIKA
Godina XLIV
Broj 2, 2019.
Strane: $56-75$

\title{
PERFORMANCE OF HYBRID PHOTOVOLTAIC/THERMAL CROP DRYER IN HOT HUMID NIGERIAN REGION
}

\author{
Sampson Uzoma ${ }^{1}$, Nnaemeka Nwakuba ${ }^{* 2}$ and Kelechi Anyaoha ${ }^{1}$ \\ ${ }^{I}$ Department of Agricultural and Bio-Environmental Engineering, \\ Imo State Polytechnic, Umuagwo, Nigeria \\ ${ }^{2}$ Department of Agricultural and Bioresources Engineering, \\ Michael Okpara University of Agriculture, Umudike, Nigeria
}

\begin{abstract}
This paper presents a study carried out to investigate the performance of a hybrid photovoltaic/thermal crop dryer in hot humid region of Umuagwo-Ohaji in the South-east region of Nigeria, through energy and exergy analyses, drying, electrical and thermal efficiencies, energy utilization and energy utilization ratio, sustainability indicators such as waste energy ratio (WER), sustainability index (SI) and improvement potential (IP). Drying experiments were conducted at varying inlet air temperatures (50, 60 and $\left.70^{\circ} \mathrm{C}\right)$, airflow rates $\left(1.14,2.29\right.$ and $\left.3.43 \mathrm{kgs}^{-1}\right)$ and slice thicknesses $(10,15$ and $20 \mathrm{~mm}$ ) on $500 \mathrm{~g}$ batch size of red pepper slices during sunshine periods. Results obtained show that the total and specific energy consumption for drying a batch of sliced red pepper samples varied between $2.08-34.91 \mathrm{~kJ}$ and $7.04-62.76 \mathrm{kJkg}^{-1}$, respectively. The energy utilization and energy utilization ratio during the drying process ranged from $195.75-3013.21 \mathrm{Js}^{-1}$ and $1.82-20.4 \%$, respectively. The energy and exergy efficiencies varied between $15.67-38.17 \%$ and $26 \%$ to $88 \%$, respectively. The mean drying efficiency of the system ranged from $7.12-40.27 \%$. The maximum electrical and thermal efficiencies of $23.86 \%$ and $93.03 \%$, respectively were obtained. A waste energy ratio of $0.0827-0.1579$ was obtained, whereas SI and IP values ranged between $1.137 \leq$ SI $\leq 6.119$ and $0.198 \leq$ IP $\leq 0.583 \mathrm{~kW}$, respectively. There is certainly a wide range of improvement in the PV/T system as $12.1-18.4 \%$ of the solar irradiance was consumed for drying. Prospects for improvement and recommendations for further studies were suggested.
\end{abstract}

Key words: Energy, exergy, PV-T system, sustainability indicators, thermal conversion.

\footnotetext{
* Corresponding Author. E-mail address: nrnwakuba@gmail.com
} 


\section{INTRODUCTION}

Nigeria is a tropical country, characterized with seasonally damp and humid climate as well as four distinguishable climate types (tropical rainforest climate, tropical savannah climate, tropical dry climate and Alpine climate).

It is strategically located within the global high sunshine belt, receiving an estimated solar radiation in the range of $3.5-7.0 \mathrm{kWm}^{-2} \mathrm{day}^{-1}$ and $3,000 \mathrm{hr}$ of annual sunshine [1]. Nevertheless, this advantageously placed it to harness considerable amount of solar energy all year round for crop drying operation. Daily and seasonal variations in solar radiation as well as persistent absorption by rain and regular cloud cover in many parts of the country have negatively affected the effective use of the sun's energy for crop drying application [2]. Nevertheless, the high rainfall intensity, especially in the South-East region of Nigeria, as result of coastal influence causes great concern as it poses a great challenge to crop drying.

Food drying has recently become a common unit operation in the drying industries for preservation of end products of food materials as well as an intermediate operation [3]. Fresh fruits and vegetables are known for their high perishable nature as a result of their relatively high moisture content (70 to $95 \%$ wet basis) at harvest which requires long drying time, low thermal conductivity during the falling rate drying period which inhibits convective heat transfer to the inner sections of the product structure, relatively low energy efficiency of dryers, and high latent heat of water evaporation [4, 5]. Drying operation is considered to be the most energy intensive unit operation because of the high latent heat of vaporization of water and inefficient heat transfer by the air stream [6, 7]. Thus, reducing the cost of energy sources to enhance dryer efficiency for good quality dried food products is one of the major challenges in drying technology [7 - 9]. It is therefore, important to perform a thermal analysis of a forced convective thin layer drying process to provide energy savings and optimum operational conditions [3].

Convective hot air crop drying using artificial dryers requires substantial amount of energy input when compared to other production processes as a result of relatively low energy efficiency of the dryer (approximately 30\%), inefficient heat transfer between convective air and food material, large quantity of energy loss through the exhaust air (even as temperature reaches the wet bulb temperature), and increased latent heat of vaporization of water [10 - 12]. In most developed nations, the energy consumption for drying operations accounts for $7-25 \%$ of the nation's total industrial energy demand [13]. In this regard, it is important to carry out an effective energy and exergy-based performance analyses of hybrid solar-electric drying process to provide energy savings and optimal process conditions. According to Nazghelichi et al. [3] and Aviara et al. [6], energy analysis is a basis for estimating different energy conservation processes as well as evaluating quantitatively the energy requirements of a drying system. Energy analysis applies the principle of energy conservation, that is, first law of thermodynamics; whereas exergy analysis considers the availability of energy at different points in the system. Exergy is defined as the maximum amount of work which can be produced by a quantity or stream of matter, heat or work as it comes to equilibrium with a reference environment [14]. 
Due to certain deficiencies and shortcomings of energy analysis, such as, inability to distinguish the different energy qualities which depends on temperature of the heat source, cannot explain the reason for the inability of conversion of heat to useful work by thermodynamic process, etc. Exergy analysis has become as a more useful tool for performing engineering evaluations [7]. It gives a clearer understanding of the effect of thermodynamic parameters on the process efficiency, to provide optimal process conditions and to decrease the impact of drying on the environment $[7,8,16,17]$. In system design, exergetic analysis gives useful information on the selection of the most suitable component design and operation procedure. This is mostly beneficial in determining the plant cost of operation, energy conservation, fuel versatility and environmental impact $[8,9]$.

Solar photovoltaic converts the sun's energy into direct current. It is regarded as one of the most significant and rapidly developing renewable energy technologies, with notable future applications. Hegazy [18] classified solar energy applications into two categories, namely: thermal system (T) and photovoltaic system (PV) cell. In the later, high solar flux incident on the PV panel gives rise to high electrical output. This system is referred to as photovoltaic-thermal system or hybrid (PV/T) and has the advantage of generating both thermal and electrical energy simultaneously. During dry season with high solar radiation intensity, the solar panel temperature rises up to 50 to $60^{\circ} \mathrm{C}$ which results in output power reduction of about $3-5 \%$ [19]. Increase in the surface temperature of PV panel, results in gross reduction in the efficiency of solar energy to electricity conversion rate, as not all the incident radiation on the PV panel can be converted to electrical energy [20]. In accordance to first law of thermodynamics, the remaining portion of the absorbed energy is converted to heat and leads to efficiency drop of the PV panel. In order to cushion this effect, researchers [18, 20, 21] have incorporated axial fans and fluid circulation channels to cool the panel temperature in order to achieve enhanced energy conversion rate of the incident solar flux. However, in humid environment, the PV panel surface can be left to be cooled by natural convective air. This paper therefore, investigates the performance of a hybrid photovoltaic/thermal system in hot humid region of Owerri, South-east Nigeria, through energy and exergy efficiencies and improvement potential factors so as to make comparison for practical applications.

\section{MATERIALS AND METHODS}

\section{System Description and Experimental Procedure}

Figure 1a shows the prototype hybrid PV/T dryer, which comprises three major integral components namely: air heater units (solar collector and electrical resistance wire), solar module (with solar cells), solar batteries (deep cycle batteries), inverter and charge controller assembly, drying chamber (with two layers of drying rack made of wire mesh), and Arduino microprocessor (version C++, SPK16.000G). Solar radiation falls on the solar cells of the PV module during sunshine periods and gets converted into electrical energy and heat. The former is stored in deep cycle batteries, whereas the later was lost to convective air. This caused the PV modules to get heated up and results in loss of solar cells efficiency. 
Table 1 shows the technical specifications system components. The air heater unit (flat plate solar collector) was constructed into the shape of a wooden box (laminated plywood board) with dimension: $100 \times 65 \times 30 \mathrm{~cm}^{3}$. The solar box was lagged with $150 \mathrm{~mm}$ thick fiberglass and was covered with a plain glass. An absorber plate of about $10 \mathrm{~mm}$ steel sheet, painted dull black was formed and inserted in the solar collector box. The solar collector was judiciously designed to obtain the dimensions that will harness and effect the necessary enthalpy increase of the drying air stream to provide adequate drying air temperature. A circular opening $(15 \mathrm{~cm}$ diameter) was made in front of the solar collector box with an axial suction fan to draw in ambient air to the solar collector and subsequently into the drying chamber. A heating element was mounted directly under the drying chamber, on top a suction axial fan (Fig. 1b). The solar collector and the drying chamber units were jointed as an integral unit through a hood. The drying chamber was constructed with lagged metal sheet forming a dimension: 50 x 50 x 50 $\mathrm{cm}^{3}$.

Transducer sensors were mounted beside the drying racks to measure and record the air temperature, relative humidity and mass loss. Temperature and humidity sensors were also placed at the different points of the dryer to measure the temperature and relative of the chimney, electric heating chamber, solar collector box and ambient environment (solar module). These transducers were connected to a control unit, housing Arduino micro-processor, which automatically displays insitu readings on a liquid crystal display (LCD).the control unit also has a 4 x 4 matrix keypad for inputting desired air temperature and air velocity thresholds. The integral hybrid system was mounted on angle-iron frame with the solar collector tilted at an angle of $15.54^{\circ}$ and faced towards the North-South axis for maximum collection of solar radiation.

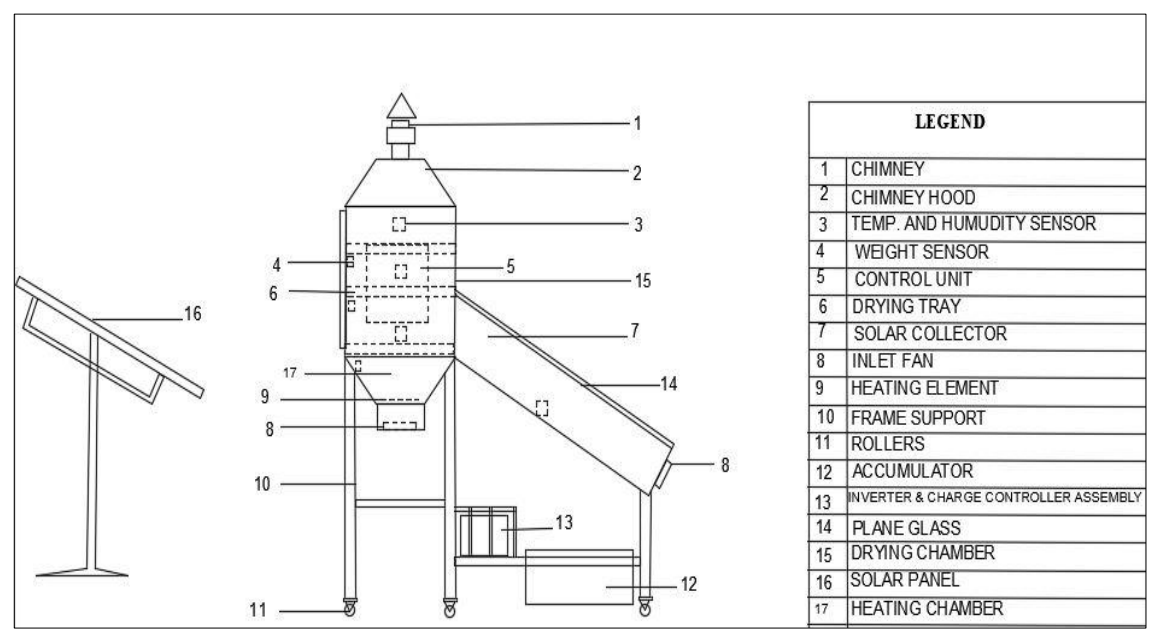

(a) 


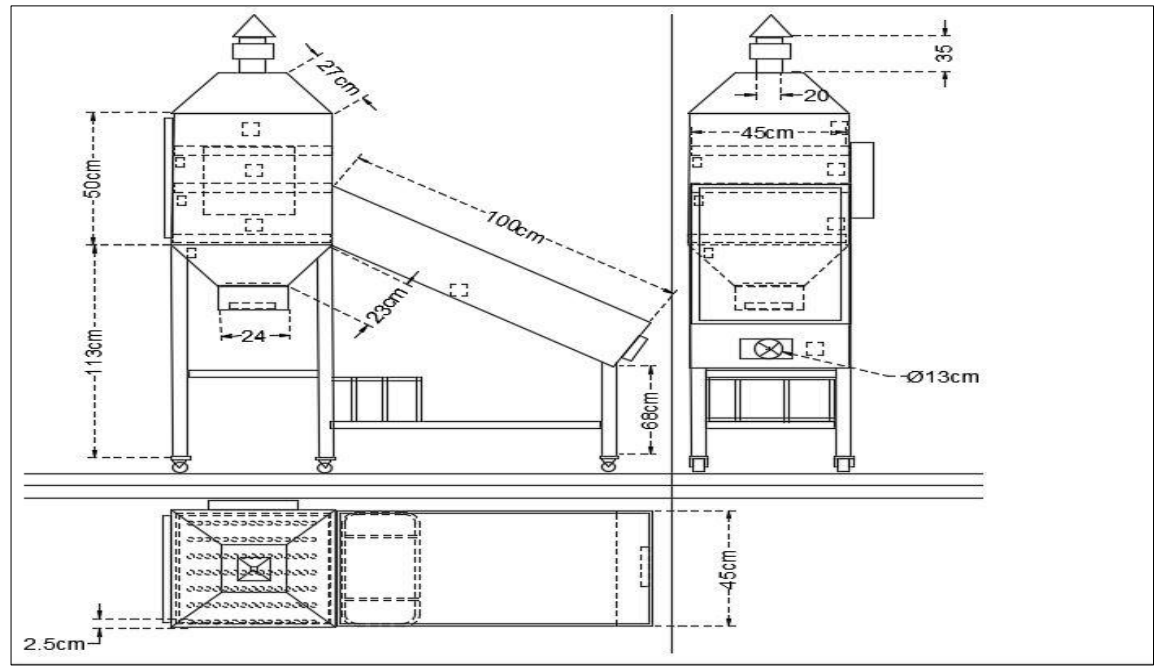

(b)

Figure 1. Isometric (a) and orthographic (b) views of the hybrid PV/T systems.

Table 1. Technical specifications of hybrid dryer components.

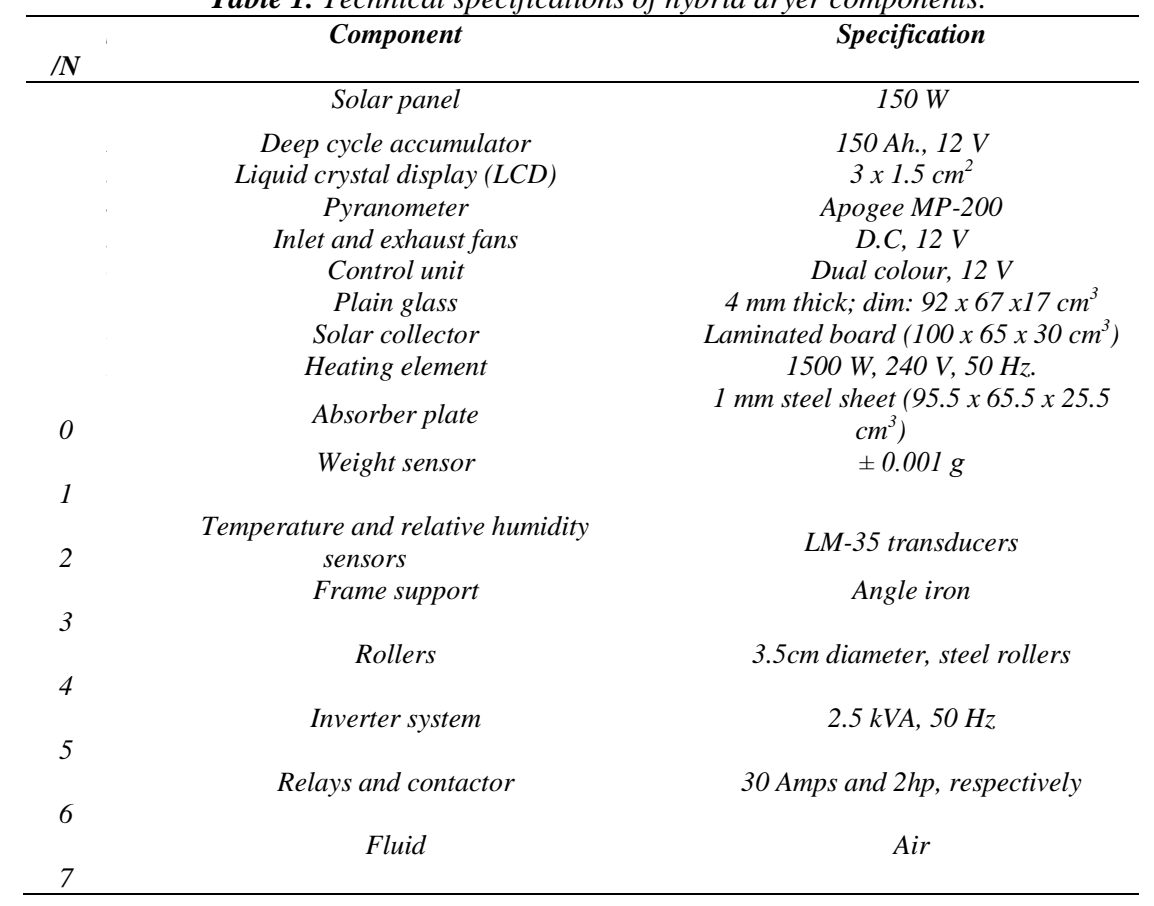


A local variety of fresh red pepper was purchased from a nearby market in Owerri, Nigeria. The samples were sorted according to viability and fully red colour. A 500g sample batch size was selected using a digital weighing balance $( \pm 0.01 \mathrm{~g}$, Camry instruments, China) and sliced to three different thicknesses (10,15 and $20 \mathrm{~mm})$ using a stainless steel knife and a digital vernier caliper (accuracy $\pm 0.05 \mathrm{~mm}$ ) with the cutting direction at perpendicular to the sample vertical axis. An average initial moisture content of the samples $(81.94 \%$ w.b) was determined gravimetrically by drying a $20 \mathrm{~g}$ representative sample at $105^{\circ} \mathrm{C}$ for 24 hours [4]. The samples were in thin-layers on the drying racks in the direction of axial flow of hot air stream uniform drying and increased drying rate.

The hybrid dryer was positioned in an open environment of Imo State Polytechnic, Umuagwo-Ohaji, South-eastern region of Nigeria; and the quantity of incident solar radiation and temperature on the solar collector was measured using a pyranometer (Apogee MP-200) to evaluate the solar collector thermal profile. Drying experiments were conducted during sunshine hours (9:00 - 17:00hrs) using the hybrid heat units. The dryer was switched to allow steady-state condition to be attained by the drying chamber. Sliced red pepper samples with initial moisture content of $81.94 \%$ w.b were introduced and dried at three varying air temperatures $\left(50,60\right.$ and $\left.70^{\circ} \mathrm{C}\right)$, airflow rates $(1.14,2.29$ and $\left.3.43 \mathrm{kgs}^{-1}\right)$ and slice thicknesses $(10,15$ and $20 \mathrm{~mm}$ ) using the $4 \times 4$ matrix keypad panel. The amount of moisture loss were recorded by the weight sensors in 30-minutes intervals. The total energy consumption and drying time per batch were recorded. The experiment was replicated three times at varying air temperatures, airflow rates, and sample thicknesses for the same batch size. Each experimental batch was ended when the samples attained a mass loss corresponding to a desired storage moisture level of $10 \%$ w.b. $[22,23]$.

\section{Theoretical Principle}

The total and specific energy consumption for drying a batch of red pepper slices were obtained as reported by Nwakuba et al. (2019). The performance analyses of the hybrid PV/T dryer is grouped into electrical and thermal performances. The electrical efficiency $\left(\eta_{\mathrm{e}}\right)$ is dependent upon the incident solar flux and the panel surface temperature, and is expressed as Eq. (1); whereas the thermal efficiency $\left(\eta_{\mathrm{th}}\right)$ at steadystate condition is a function of the incident solar radiation and airflow rate, expressed as Eq. (2) [24]:

$$
\begin{gathered}
\eta_{e}=\frac{I_{m} V_{m}}{A G} \\
\eta_{\text {th }}=\frac{\mathrm{mc}_{p}\left(\mathrm{~T}_{\mathrm{o}}-\mathrm{T}_{\mathrm{i}}\right)}{\mathrm{AG}}
\end{gathered}
$$

Where: $\mathrm{I}_{\mathrm{m}}$ and $\mathrm{V}_{\mathrm{m}}=\mathrm{PV}$ module current $(\mathrm{A})$ and voltage $(\mathrm{V})$ respectively; $\mathrm{A}=$ Area of PV module $\left(\mathrm{m}^{2}\right) ; \mathrm{G}=$ incident solar radiation $\left(\mathrm{Wm}^{-2}\right) ; \dot{\mathrm{m}}=$ mass flow rate of air $\left(\mathrm{kgs}^{-}\right.$ $\left.{ }^{1}\right) ; c_{p}=$ specific heat capacity of air $\left(\mathrm{Jkg}^{-1} \mathrm{~K}\right) ; \mathrm{T}_{\mathrm{i}}$ and $\mathrm{T}_{\mathrm{o}}=$ inlet and outlet air temperatures $\left({ }^{\circ} \mathrm{C}\right)$, respectively. 
The overall system efficiency $\left(\eta_{o}\right)$ is expressed as Eq. (3):

$$
\eta_{\mathrm{o}}=\eta_{\mathrm{e}}+\eta_{\mathrm{th}}
$$

The energy efficiency $\left(\eta_{e n}\right)$ of the hybrid PV/T system, referred to as the ratio of the total (electrical and thermal) energy, $Q_{t}$ to the solar energy incident on the PV module is expressed as Eq. (4) [21]:

$$
\eta_{\text {en }}=\frac{\mathrm{Q}_{\mathrm{t}}}{\mathrm{GA}}
$$

The drying efficiency of a hybrid PV/T dryer $\left(\eta_{d}\right)$, is defined as the ratio of total energy consumed for sample moisture evaporation to the quantity of energy supplied to by the hybrid system, as expressed in Eq. (5) as [25, 26]:

$$
\eta_{\mathrm{d}}=\frac{\mathrm{M}_{\mathrm{m}} \mathrm{L}}{\mathrm{GA}+\mathrm{F}_{\mathrm{p}}+\mathrm{Q}_{\mathrm{PV} / \mathrm{T}}}
$$

Where: $\mathrm{M}_{\mathrm{m}}$ = amount of moisture evaporated $(\mathrm{kg}) ; \mathrm{L}=$ latent heat of vaporization of moisture $\left(\mathrm{kJkg}^{-1}\right) ; \mathrm{F}_{\mathrm{p}}=$ power rating of the axial fan $(\mathrm{W}) ; \mathrm{Q}_{\mathrm{PV} / \mathrm{T}}=$ energy from $\mathrm{PV} / \mathrm{T}$ system $(\mathrm{kJ})$.

The energy utilization $\left(E_{u}\right)$ was obtained using Eq. (6) $[6,8]$ :

$$
\mathrm{E}_{\mathrm{u}}=\mathrm{M}_{\mathrm{a}}\left(\mathrm{h}_{\mathrm{a} 1}-\mathrm{h}_{\mathrm{a} 2}\right)
$$

Where: $h_{a 1}$ and $h_{2 a}=$ enthalpies of the ambient dry air at inlet and outlet points, respectively $\left(\mathrm{kJkg}^{-1}\right)$.

The energy utilization ratio (EUR) defined as the ratio of energy used for moisture evaporation to energy supplied by the hybrid dryer heat source was calculated using Eq. (7) $[6,8]$ :

$$
\operatorname{EUR}=M_{\mathrm{a}}\left(\frac{\mathrm{h}_{\mathrm{a} 1}-\mathrm{h}_{\mathrm{a} 2}}{\mathrm{~h}_{\mathrm{a} 1}-\mathrm{h}_{\mathrm{a}}}\right)
$$

Where: $h_{a}=$ enthalpy of the ambient dry air $\left(\mathrm{kJkg}^{-1}\right)$.

Exergy efficiency $\left(\eta_{\mathrm{ex}}\right)$ is important to evaluate the actual performance of PV/T system of the hybrid dryer. It is expressed as Eq. (8) [21]:

$$
\eta_{\mathrm{ex}}=\frac{\dot{\mathrm{E}_{\mathrm{x}}}}{\mathrm{s}_{\mathrm{ex}}}
$$

Where: $\mathrm{E}_{\mathrm{x}}$ and $\mathrm{S}_{\mathrm{ex}}=$ exergy from $\mathrm{PV} / \mathrm{T}$ system and exergy from solar radiation incident on the PV module surface (kJ), respectively. Eq. (6) can be further expressed as Eqs. (9) and (10) [21]: 


$$
\begin{gathered}
\dot{E}_{x}=I_{m} V_{m}+\left(1-\frac{T_{a}}{T_{m}}\right)\left[h_{a m} A\left(T_{c}-T_{a}\right)\right] \\
S_{e x}=\left(1-\frac{T_{a}}{T_{m}}\right) G A
\end{gathered}
$$

Where: $\mathrm{T}_{\mathrm{a}}$ and $\mathrm{T}_{\mathrm{m}}=$ ambient and module temperatures $\left({ }^{\circ} \mathrm{C}\right)$, respectively; $\mathrm{h}_{\mathrm{am}}=$ convective heat coefficient from ambient to module temperature $\left({ }^{\circ} \mathrm{C}\right)$.

\section{Sustainability indicators}

Drying operations involve heat generation, utilization and transfer; its influence on the surrounding environment is considered for sustainable development. Sustainability indicators vary air temperature and air velocity during drying process [22, 26, 27]. This study considers the following sustainability indicators: improvement potential (IP), waste exergy ratio (WER) and sustainability index (SI). They were calculated using Eqs. (11) - (13), respectively:

$$
\begin{gathered}
\text { WER }=\frac{\mathrm{Ex}_{1}}{\mathrm{Ex}_{\mathrm{i}}} \\
\mathrm{SI}=\frac{1}{1-\eta_{e x}} \\
\mathrm{IP}=\left(1-\eta_{e x}\right) \mathrm{E}_{\mathrm{XI}}
\end{gathered}
$$

Where: $\eta_{e x}=$ overall exergy efficiency expressed in Eq. (14) as:

$$
\eta_{\mathrm{ex}}=\frac{E x_{\mathrm{i}}-E \mathrm{Ex}_{1}}{\mathrm{Ex}_{\mathrm{i}}}
$$

Where: $\mathrm{E}_{\mathrm{xl}}=$ exergy loss of the drying chamber $=\mathrm{E}_{\mathrm{xi}}-\mathrm{E}_{\mathrm{o}}\left(\mathrm{kJs}^{-1}\right) ; \mathrm{E}_{\mathrm{xi}}$ and $\mathrm{E}_{\mathrm{xo}}=$ exergy inlet and exergy outlet of the drying chamber $\left(\mathrm{kJs}^{-1}\right)$, respectively.

In this study, the ambient air temperature and relative humidity were measured as $\mathrm{T}_{\mathrm{m}}=295.7 \mathrm{~K}$ and $\varphi=35 \%$, respectively.

\section{RESULTS AND DISCUSSION}

\section{System performance efficiency}

The electrical $\left(\eta_{\mathrm{e}}\right)$, thermal $\left(\eta_{\mathrm{th}}\right)$ and overall $\left(\eta_{\mathrm{o}}\right)$ efficiencies of the hybrid PV/T dryer were calculated with Eqs. (1) to (3) at different hourly time and solar irradiance during sunshine period, as presented in Fig. 2. It was observed that both electrical and thermal efficiencies depend on the solar radiation intensity which is a function of hourly time. Increase in the temperature of the PV module decreases the electrical and thermal efficiencies of the dryer as a result of the system's low energy conversion rate of the incident solar flux at high module surface temperatures. 
The maximum electrical $(23.86 \%)$ and thermal $(69.16 \%)$ efficiencies were obtained at 10:00am at solar radiation intensity of $644.95 \mathrm{Wm}^{-2}$. Whereas the maximum thermal efficiency (were obtained may reach $60 \%$ to $70 \%$ during the system operation. Maximum solar irradiance $\left(959.26 \mathrm{Wm}^{-2}\right)$ was obtained at $1: 00 \mathrm{pm}$ with corresponding low electrical and thermal efficiencies of $14.3 \%$ and $59.43 \%$, respectively. The overall efficiency of the system during operation varied between $71.81 \% \leq \eta_{\mathrm{o}} \leq 93.03 \%$. This is an indication of satisfactory performance since the PV module is cooled by natural convection [20].



Time of the day (hrs)

Fig. 2. Mean electrical, thermal and overall efficiencies at varying time and solar irradiance during sunshine periods.

The energy efficiency of the drying system is referred to as the ratio of energy utilized for removal of moisture to the total energy consumed during drying process. It then indicates that more energy was used increasing drying air temperature and product slice thickness at constant airflow rate (Figure 3). The energy efficiency reduces with increase in mass flow rate of the drying air; which varied between 15.67 to $38.17 \%$ as the drying air temperature and slice thickness increased from 50 to $70^{\circ} \mathrm{C}$, and 10 to $20 \mathrm{~mm}$, respectively at airflow rates of $3.43 \mathrm{kgs}^{-1}$ and $1.14 \mathrm{kgs}^{-1}$. Similar results have been reported for cassava starch drying and apple slices $[6,10]$, respectively. 


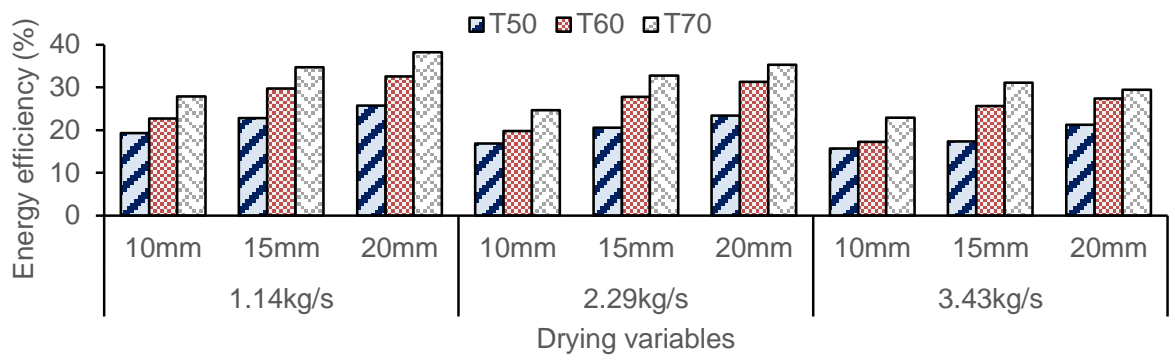

Figure 3. Variation of energy efficiency with drying air temperature, airflow rate and slice thickness.

However, at constant airflow rate, increasing the drying air temperature and slice thickness increases the drying efficiency of the system (Table 2). This was attributed to higher evaporative power of the drying air at increasing air temperatures, which reduce the water vapour pressure within the sample product, thus enhancing the drying rate. Increasing the airflow rate of the drying air increases the heat transfer rate within the system [29], as well as heat removal factor of the solar collector absorbing plate and electric heating unit. However, heat removal increases from these two heating units which yields an increase in the total useful heat of air, which enhances drying efficiency $[30,31]$. From Table 2, the mean drying efficiency of the hybrid system varied between $7.12-40.27 \%$. This agrees with $[10,25,32]$ who reported drying efficiency values ranging between $2.50-54.37 \%$.

Table 2: Mean values of drying efficiency at varying drying conditions.

\begin{tabular}{|c|c|c|c|c|c|c|c|c|c|}
\hline $\begin{array}{c}\text { Slice } \\
\text { thickness } \\
(\mathrm{mm})\end{array}$ & & 10 & & & 15 & & & 20 & \\
\hline \multicolumn{10}{|l|}{ Airflow } \\
\hline $\begin{array}{l}\text { rate } \\
\left(k^{\prime-1} s^{-1}\right)\end{array}$ & 1.14 & 2.29 & 3.43 & 1.14 & 2.29 & 3.43 & 1.14 & 2.29 & 3.43 \\
\hline $\begin{array}{l}\text { Drying air } \\
\text { temp. }\left({ }^{o} \mathrm{C}\right)\end{array}$ & \multicolumn{9}{|c|}{ Drying efficiency (\%) } \\
\hline 50 & 7.12 & 12.42 & 15.45 & 13.66 & 17.54 & 21.43 & 20.27 & 25.12 & 29.75 \\
\hline 60 & 10.72 & 14.92 & 17.63 & 16.51 & 20.82 & 24.71 & 25.41 & 30.41 & 34.53 \\
\hline 70 & 12.81 & 16.61 & 18.38 & 19.77 & 22.49 & 28.37 & 29.94 & 33.12 & 40.27 \\
\hline
\end{tabular}

\section{Energy performance}

The total energy consumption for drying a batch of red pepper slices is shown in Figure 4. Increase in drying air temperature and airflow rate at constant slice thickness decreased the total energy consumption due to rise in kinetic energy of the product sample for rapid moisture diffusion and evaporation which increased the heat transfer rate and vapor pressure deficit for less intra-particle resistance to moisture taken place; drying time was reduced, thus reduction in the total energy consumption. Also as sample thickness increases, more energy was consumed for heat transfer to take place in the 
interior of sample due to large capillary distance. Increase in airflow rate. Energy consumption increased when drying thicker samples at increasing airflow rate due to longer time taken by internal moisture to diffuse trough the capillary structure, thus increased drying time. Generally, less energy was consumed at increased air temperature and airflow rate at any given slice thickness to dry the sliced pepper sample to the desired moisture level. The total energy consumption varied between $2.08-34.91 \mathrm{~kJ}$. These were obtained at drying air temperatures, air mass flow rates and slice thicknesses of $70^{\circ} \mathrm{C}, 3.43 \mathrm{kgs}^{-1}, 10 \mathrm{~mm}$ and $50^{\circ} \mathrm{C}, 1.14 \mathrm{kgs}^{-1}, 20 \mathrm{~mm}$, respectively.

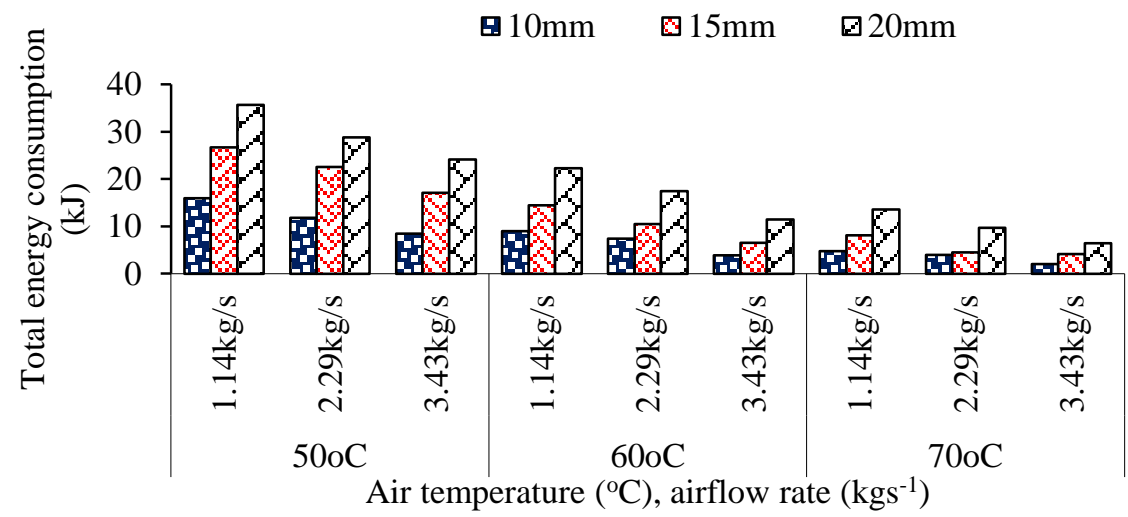

Fig. 4. Effect of drying air temperature and airflow rate at varying slice thicknesses on the total energy consumption for drying of red pepper slices.

Increase in the air temperature reduces the specific energy consumption at decreasing sliced simple thickness (Fig. 5). This is because of increased temperature gradient between the drying air and sample product which resulted in reduction in drying time, thus decreased specific energy consumption. Increasing the air temperature and airflow rate reduce the specific energy consumption due to increased heat transfer rate and water vapour pressure deficit in the sliced samples. Also increasing the airflow rate at constant air temperature decreases the specific energy consumption whereas increase in slice thickness increases it. The specific energy consumption ranged between $7.04-$ $62.76 \mathrm{kJkg}^{-1}$. 


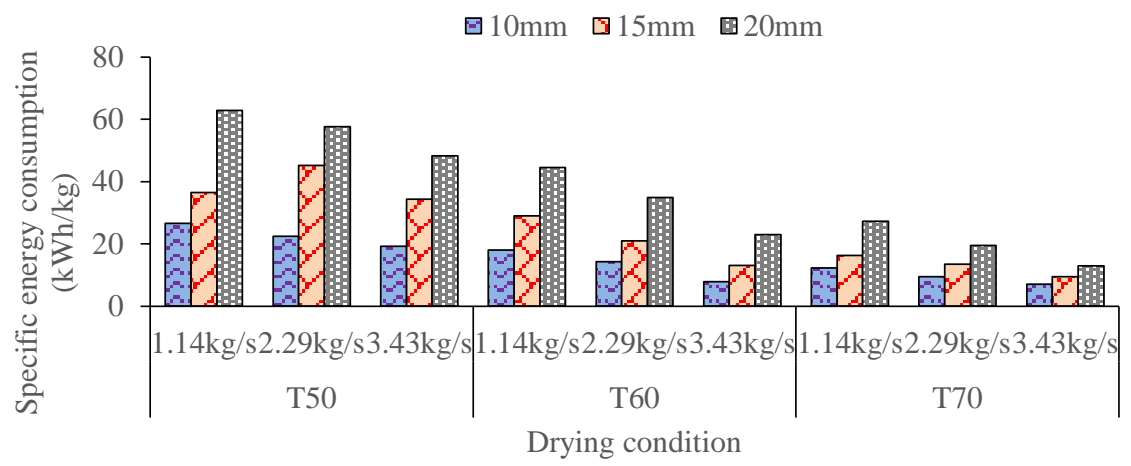

Fig. 5. Effect of air temperature and airflow rate at varying slice thicknesses on the specific energy consumption for drying of red pepper slices.

Variation in energy utilization (EU) during drying process of sliced red pepper samples at varying air temperatures, airflow rates and slice thicknesses is shown in Fig. 6. The energy consumption at constant airflow rate increases with temperature increase. This gave rise to further moisture removal in larger sample thickness because of increase in kinetic energy of the drying air that EU value. Also, EU increases with decrease in in sample slice thickness (at constant air temperature and airflow rate), because of short intra-particle capillary transfer of heat and moisture. At constant sample thickness, increasing the air temperature and airflow rate gave rise to increased EU because of increased rate of surface moisture evaporation. Similar observations were reported by $[3$, $10,32,33]$. The energy utilization obtained for drying of red pepper slices ranged from $195.75-3013.21 \mathrm{Js}^{-1}$. Similar results for eggplant slices, ball pepper slices and okra slices in a hybrid solar-electric dryer were reported by [33 - 35].

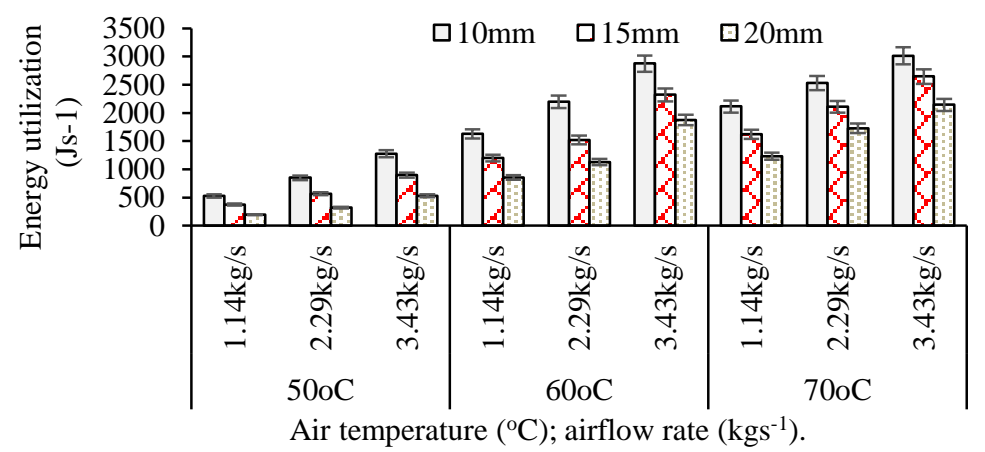

Fig. 6. Energy utilization at varying drying parameters.

The energy utilization ratio (EUR) at varying drying conditions of red pepper slices is presented in Fig.7. Increase in air temperature increases EUR but decreases it with increase in airflow rate. Increasing the slice thickness (at constant drying air temperature 
and airflow rate) decreases EUR, as a result of low kinetic energy of the drying air which gave rise to reduced heat and mass transfer rate. The EUR values obtained varied between $1.82-20.4 \%$ at drying air temperature of $50^{\circ} \mathrm{C}$, slice thickness of $20 \mathrm{~mm}$, mass flow rate of $3.43 \mathrm{kgs}^{-1}$ and drying air temperature of $70^{\circ} \mathrm{C}$, slice thickness of $10 \mathrm{~mm}$, mass flow rate of $1.14 \mathrm{kgs}^{-1}$, respectively. These values are within the range of the reports of Aghbashlo et al. [35]; Akpinar [34]; Corzo et al. [36], which show that the energy utilization of the drying system was efficiently utilized for drying of red pepper slices, especially at higher air temperatures. Generally, reducing the slice thickness and airflow rate at increased drying air temperature yield high energy utilization ratio, therefore seems to be an important thermodynamic parameter for analyzing the net quantity of energy utilized during thin-layer drying process.

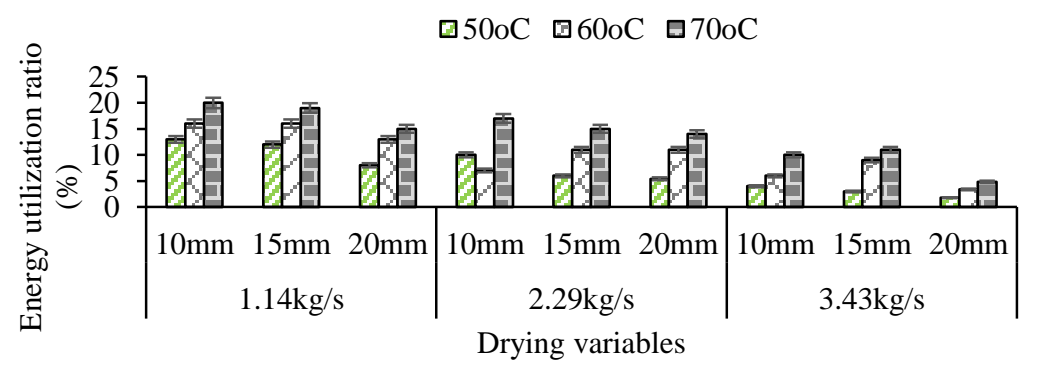

\section{Exergy efficiency}

The exergy efficiency as a function of drying time is illustrated by the decreasing trend of the curve in Fig. 8. During the first 6.5 hours of drying, the curve changed to a decreasing pattern and sharply increased towards the later period of the day, following a $3^{\text {rd }}$-order polynomial function. This initial decrease in the exergy efficiency was probably as a result of substantial increase in exergy loss of the drying chamber at increasing air temperature. Similar observation was reported by BoulemtafesBoukadoum and Benzaoui [37] in the drying of mint.

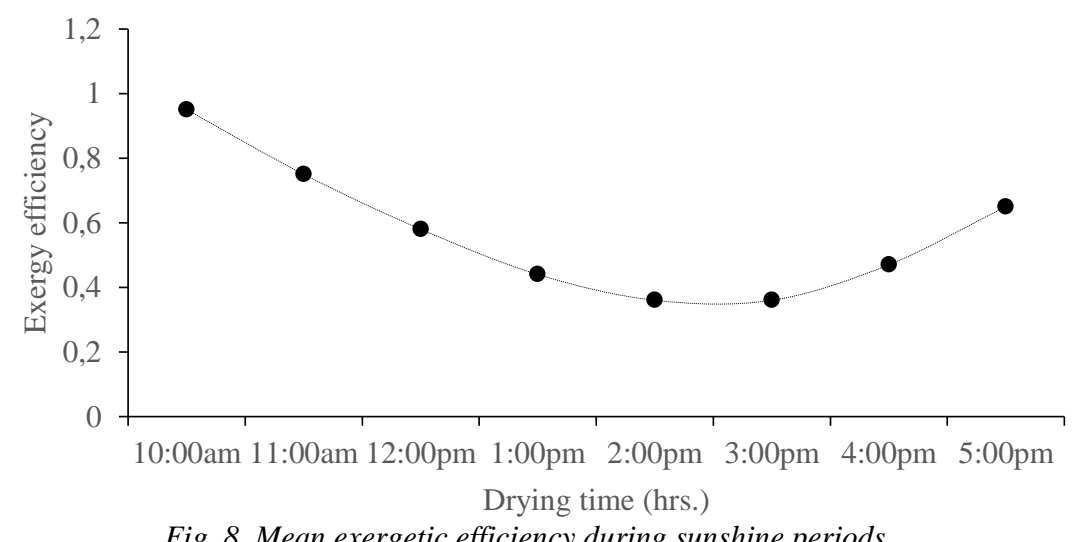

Fig. 8. Mean exergetic efficiency during sunshine periods. 
Figure 9., shows the variations of exergy efficiency at varying drying conditions of the hybrid PV/T dryer. Increase in the drying air temperature and airflow rate reduced the exergy efficiency of the dryer, because of substantial exergy loss. Increase in inlet air temperature (with higher exergy) increases the internal moisture diffusion and surface evaporation of the product as well as the exergy utilization, thus increase in exergy loss. However, supply of heat energy by the hybrid heat units caused enormous reduction in the exergetic efficiency of the drying chamber. The exergetic efficiency obtained varied between $26 \% \leq \eta_{\mathrm{ex}} \leq 88 \%$. This is an indication of substantial quantity of supplied thermal exergy of the dryer system being lost to the exhaust drying air.

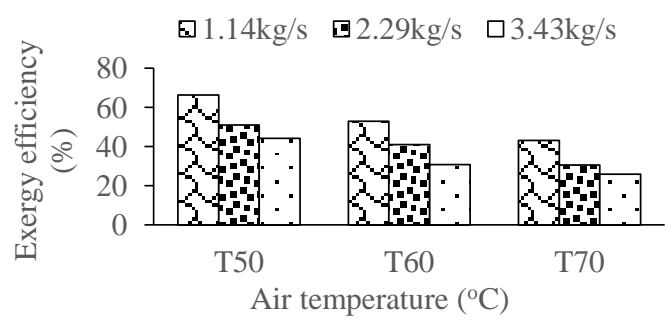

(a)

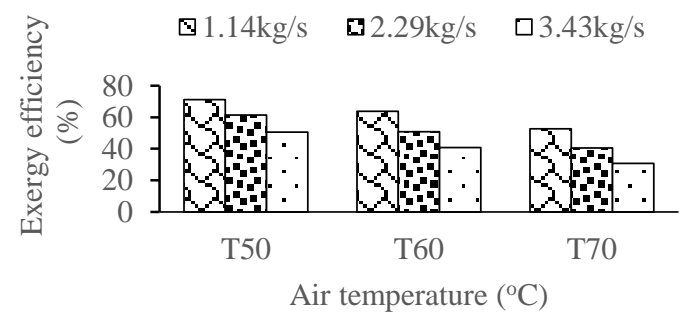

(b)

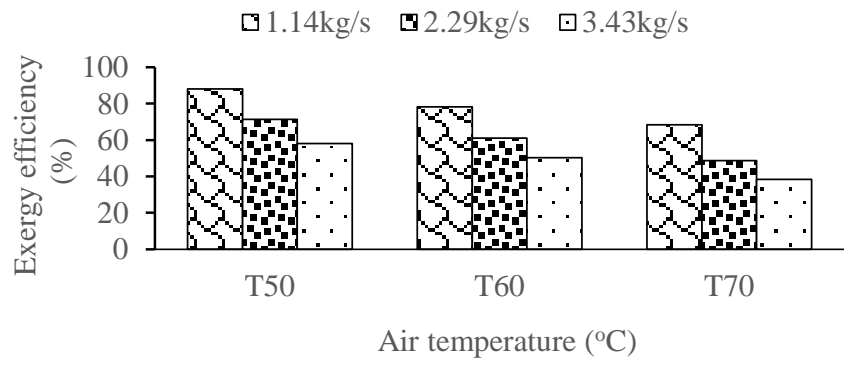

(c)

Fig. 9. Variations of exergetic efficiency with drying air temperature and airflow rate at: (a) $10 \mathrm{~mm},(b) 15 \mathrm{~mm}$ and (c) $20 \mathrm{~mm}$ slice thicknesses. 


\section{Sustainability indicators}

The need to raise the drying air temperature above the ambient results in loss of exergy to the exiting air. In comparison of this lost exergy with the exergy inflow into the drying chamber is referred to as waste exergy ratio (WER), which was calculated with Eq. (11). The effect of varying air temperatures and airflow rates (at constant slice thickness) on WER is shown in Fig. 10. At increased air temperature and airflow, more exergy is lost to the exiting air, hence increased WER. The values of WER obtained range between $0.0827 \leq \mathrm{WER} \leq 0.1579$, which are close to the result obtained by Ndukwu et al [8].

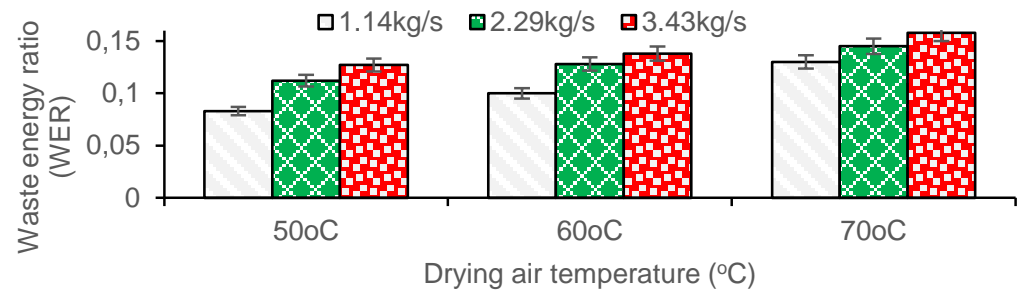

Fig. 10: Waste exergy ratio of red pepper slices in a hybrid solar-electric dryer.

Variation of the exergy sustainability index (SI) with varying air temperatures and airflow rates was calculated with Eq. (12) and presented in Figure 11. Air temperature decrease increases SI at increasing airflow rate. This results in increase in the exergy efficiency, which reduces environmental impact [38]. The values of SI obtained varied between: $1.137 \leq \mathrm{SI} \leq 6.119$. These values compared closely with the results of $[8,36]$ for solar dryers, which are in the range of $3.01-8.15$ and $1.9-5.1$, respectively. Therefore, improving the exergetic efficiency of the dryer is paramount in maintaining low environmental impact.

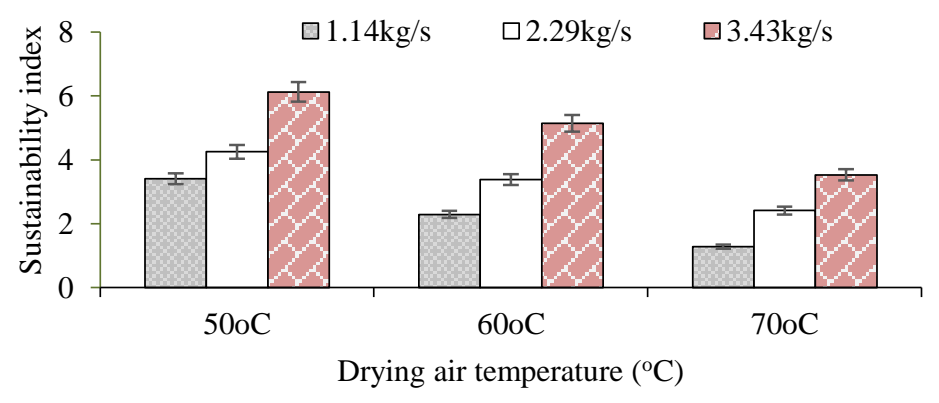

Fig. 11: Exergetic sustainability index at varying drying air temperature and air mass flow rate.

Fig. 12 illustratively presents the improvement potential (Eq. 13) of the drying system together with the exergy of the solar irradiance and exergy of the system. 
The exergy of the solar irradiance varies between $0.311-0.77 \mathrm{~kW}$ at $5 \mathrm{pm}$ and $1 \mathrm{pm}$, respectively; whereas the improvement potential ranges from $0.198-0.583 \mathrm{~kW}$ at $5 \mathrm{pm}$ and $1 \mathrm{pm}$, respectively. The exergy of the hybrid PV/T system obtained varies from $0.0592-0.111 \mathrm{~kW}$ at $9 \mathrm{am}$ and $1 \mathrm{pm}$, respectively. The improvement potential of the hybrid dryer is a function of the difference between the inlet and outlet exergy of the drying chamber as well as the exergy efficiency [21]. A substantial quantity of exergy entering the drying chamber is wasted and goes into exergy destruction as depicted by the large difference. Therefore, the exergy efficiency would be reduced and the improvement potential (IP) would grossly increase. It can be deduced from Fig. 12 that large scope for system improvement exists as only $12.1-18.4 \%$ of the exergy from the solar radiation was utilized [21].

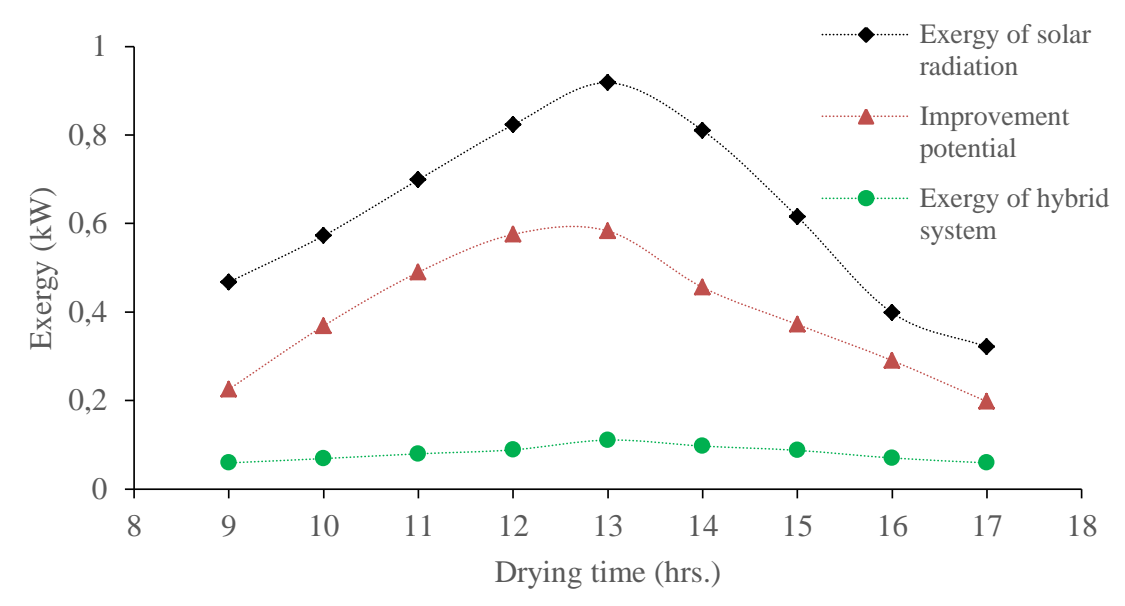

Fig. 12: Hourly variation of exergies of the drying chamber, solar radiation and improvement potential of the hybrid PV/T system.

The effect of drying chamber temperature on improvement potential (IP) is shown in Fig. 13. A linear relationship with high coefficient of correlation exists between the drying air temperature and IP. Improvement potential depends on exergy efficiency, which decreases with increasing air temperature and exergy loss, thus high improvement potential of the system $[6,7,36]$. The effect airflow rate was not noticeable on IP yield (Castro et al., 2018). The values of IP obtained varied between $0.099 \leq \mathrm{IP} \leq-0.289 \mathrm{~kW}$. 


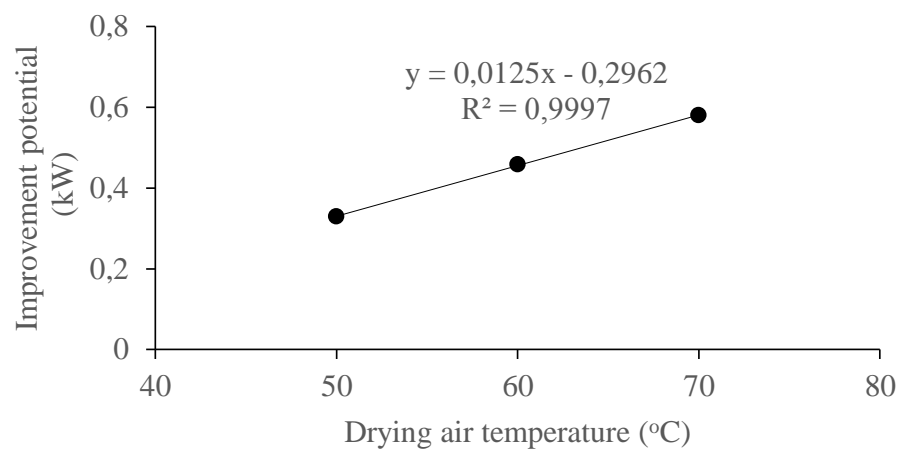

Figure 13: Effect of drying air temperature on the exergetic improvement potential.

\section{CONCLUSIONS}

A comprehensive performance analysis of a hybrid PV/T dryer in hot humid Nigerian environment applied to drying of red pepper slices is discussed. Based on the experimental findings of this study, the following conclusions can be drawn:

- The system performed satisfactorily during sunshine period of the drying process. The maximum electrical, thermal and overall efficiencies obtained were $23.86,69.16$ and $93.03 \%$, respectively. Maximum solar irradiance $\left(959.26 \mathrm{Wm}^{-2}\right)$ was obtained at 1:00pm with corresponding low electrical and thermal efficiencies of $14.3 \%$ and $59.43 \%$, respectively.

- Energy efficiency reduces as air temperature, airflow rate and slice thickness increase. It varied between 15.67 to $38.17 \%$.

- The mean drying efficiency of the hybrid system varied between $7.12-$ $40.27 \%$.

- The total and specific energy consumption for drying 500g batch of red pepper sliced samples in a hybrid PV/T dryer varied between $2.08-34.91 \mathrm{~kJ}$ and $7.04-$ $62.76 \mathrm{kJkg}^{-1}$, respectively. Increasing the drying air temperature and airflow rate at constant slice thickness reduced the total and specific energy consumption, whereas increase in slice thickness increased the total and specific energy consumption.

- The energy utilization during the drying process ranged from $195.75-3013.21$ $\mathrm{Js}^{-1}$, whereas the energy utilization ratio varied between $1.82-20.4 \%$.

- The exergy efficiency decreased with drying time as temperature and airflow rate increased. It varied from $26 \%$ to $88 \%$. 
- The sustainability indicators show that waste energy ratio varied between $0.0827 \leq$ WER $\leq 0.1579$; whereas sustainability index and improvement potential varied from: $1.137 \leq \mathrm{SI} \leq 6.119$ and $0.198 \leq \mathrm{IP} \leq 0.583 \mathrm{~kW}$, respectively.

- It is therefore, suggested that exergy performance analysis and assessment of $\mathrm{PV} / \mathrm{T}$ be conducted in order to model, evaluate, plan and apply PV/T systems to crop dryers. There is wide scope of system improvement for better performance. Air circulation device may be incorporated to remove generated heat from the PV modules in order to enhance the system's energy and exergy efficiencies, as well as to improve the energy conversion rate.

\section{REFERENCES}

[1] Augustine, C. and Nnabuchi, M.N. 2010. Analysis of some meteorological data for some selected cities in the Eastern and Southern zone of Nigeria. African Journal of Environmental Science and Technology, 4(2), $92-99$.

[2] Okoroigwe, E.C., Eke, M.N. and Ugwu, H.U. 2013. Design and evaluation of combined solar and biomass dryer for small and medium enterprises for developing countries: International Journal of Physical Sciences, 8(25), 1341- 1349.

[3] Nazghelichi, T. Kianmehr, M.H. and Aghbashlo, M. 2010. Thermodynamic analysis of fluidized bed drying of carrot cubes. Energy, 35(2010), 4679- 4684.

[4] Nwakuba, N.R., Asoegwu, S.N. and Nwaigwe, K.N. 2016. Energy requirements for drying of sliced agricultural products: a review. Ag. Eng. International. CIGR E-Journal, 18(2), 144-155.

[5] Motevali, A., Minaei, S., Banakar, A., Ghobadian, B. and Khoshtaghaza, M. H. 2014. Comparison of energy parameters in various dryers. Energy Con. and Management, 87, 711-725.

[6] Aviara, N.A., Onuoha, L.N., Falola, O.E. and Igbeka, J.C. 2014. Energy and exergy analyses of native cassava starch drying in a tray Dryer. Energy. 73 (2014), $809-817$.

[7] Erbay, Z. and Icier, F. (2009). Optimization of hot air drying of olive leaves using response surface methodology. Journal of Food Engineering, 91(2009), 533 - 541.

[8] Ndukwu, M.C., Bennamoun, L., Abam, F.I., Eke, A.B. and Ukoha, D. 2017. Energy and exergy analysis of a solar dryer integrated with sodium sulfate decahydrate and sodium chloride as thermal storage medium. Renewable Energy. 113 (2017) 1182 - 1192.

[9] Koyuncu, T., Tosun, I. and Pinar, Y. 2007a. Drying characteristics and heat energy requirement of cornelian cherry fruits (Cornus mas L.). J. of Food Eng., 78 (2007), 735 - 739.

[10] Beigi, M. 2016. Energy efficiency and moisture diffusivity of apple slices during convective drying. Food Science and Technology, 36 (1), 145 - 150.

[11] Kudra, T. 2012. Energy performance of convective dryers. Drying Techn., 30, 1190-1198.

[12] Raghvan, G.S.V., Rennie, T.J., Sunjka, P.S., Orsat, V., Phaphuangwittayakul, W. and Terdtoon, P. 2005. Overview of new techniques for drying biological materials with emphasis on energy aspects. Brazilian Journal of Chemical Engineering, (22), 195-201.

[13] Akpinar, E.K., Midilli, A. and Bicer, Y. 2005. Energy and exergy of potato drying process via cyclone type dryer. Energy Conversion Management, 46, 2530-2552.

[14] Bennamoun, L. 2012. An overview on application of exergy and energy for determination of solar drying efficiency. International Journal of Energy Engineering, 2(5), 184 - 194.

[15] Erbay, Z. and Icier, F. 2009. Optimization of hot air drying of olive leaves using response surface methodology. Journal of Food Engineering, 91(2009), 533 - 541.

[16] Koyuncu, T., Tosun, I. and Pinar, Y. 2007b. Drying characteristics and heat energy requirement of cornelian cherry fruits (Cornus mas L.). J. of Food Eng., 78 (2007), 735 - 739. 
[17] Darvishi, H., Asi, R.A., Asghari, A., Najafi, G. and Gazori, H.A. 2013. Mathematical modeling, moisture diffusion, energy consumption and efficiency of thin-layer drying of potato slices. Journal of Food Process Technology, 4(2013), 215 - 219.

[18] Hegazy, A. A. 2000. Comparative study of the performances of four photovoltaic/thermal solar air collectors. Energy Conversion and Management, 41, 861 - 881 .

[19] Kalogirou, S.A. and Tripanagnostopoulos, Y. 2006. Hybrid PV/T solar systems for domestic hot water and electricity production. J. of En. Con. and Management, 47, 3368 - 3382.

[20] Alzaabia, A.A., Badawiyeha, N. K., Hantousha, H. O. and Hamid, A. K. 2014. Electrical/thermal performance of hybrid PV/T system in Sharjah, UAE. International Journal of Smart Grid and Clean Energy, 3(4), 385-389.

[21] Joshi, A. S., Dincer, I. and Reddy, B.V. 2011. Analysis of energy and exergy efficiencies for hybrid PV/T systems. Low-Carbon Technologies, 6(1), $64-69$.

[22] Oyewola, M.O. and Adeleke, A.I. 2014. Design and construction of a hybrid dryer with temperature control, utilizing solar and electric energies. International Conference of Mechanical Engineering, Energy Technology and Management. $639-646,10-14^{\text {th }}$ May, 2014, Johannesburg, South Africa.

[23] Nwakuba, N.R., Chukwuezie, O.C., Asonye, U.G. and Asoegwu, S.N. 2019. Influence of process parameters on the energy requirements and dried sliced tomato quality. Applied Engineering in Agriculture (in press). https://doi.org/10.13031.

[24] Ibrahim, A., Othman, M.Y., Ruslan, M.H., Alghoul, M.A., Yahya, M., Zaharim, A. and Sopian, K. 2009. Performance of photovoltaic thermal collector (PVT) with different absorbers design. Journal of WSEAS Transactions on Environment and Development, 5(3), 322-330.

[25] Boughali, S., Benmoussa, H., Bouchekima, B., Mennouche, D., Bouguettaia, H. and Bechki, D. 2009. Crop drying by indirect active hybrid solar- electrical dryer in the eastern Algerian Septentrional Sahara: Solar Energy, 83(2009) 2223-2232.

[26] Fudholi, A., Yendra, R., Basri, D.F., Ruslan, M.H. and Sopian, K. (2016). Energy and exergy analysis of hybrid solar drying system. Cont. Engineering Science, 9(2016) 215 - 223.

[27] Midilli, A. and Kucuk, H. (2014). Exergy-based sustainability indicators for a single layer solar drying process. Progress in Exergy, Energy and Environment, 3(4), 705 - 712.

[28] Fu, M., Roman, C., Echegaray, M., Mazza, G. and Rodriguez, R. (2018). Exergy analyses of onion drying by convection: influence of dryer param. on performance. Entropy, 20 (2018), 2 - 9.

[29] Reyes A., Mahn, A., Huenulaf, P. and Gonzalez, T. 2014. Tomato dehydration in a hybrid solar dryer. Chemical Engineering Processing Technology, 5(2014), 1-8.

[30] Lopez-Vidana, E.C., Mendez-Lagunas, L.L. and Rodriguez-Ramirez, J. 2013. Efficiency of a hybrid solar-gas dryer. Solar Energy, 93 (2013), 23 - 31.

[31] Doymaz, I. 2004. Drying characteristics and kinetics of okra. Journal of Food Engineering, 69(2004), 275-279.

[32] Azadbakht, M., Torshizi, V.M., Ziaratban, A. and Aghili, H. 2017. Energy and exergy analysis during eggplant drying in a fluidized bed dryer. Agricultural Engineering International: CIGR E-Journal, 19(3), 177- 182.

[33] Nwakuba, N.R, Chukwuezie, O.C., Asonye, U.G. and Asoegwu, S.N. 2018. Energy efficiency and optimization of convective hot air drying conditions of okra slices. $12^{\text {th }}$ International CIGR Technical Symposium, IITA, Ibadan, Nigeria, Pp. 464 - 488.

[34] Akpinar, E.K. 2004. Energy and exergy analyses of drying of red pepper slices in a convective type dryer. Int.Communication in Heat and Mass Transfer, 31(2004), 1165 - 1176.

[35] Aghbashlo, M., Kianmehr, M.H. and Samimi-Akhijahani, H. 2008. Influence of drying conditions on the effective moisture diffusivity, energy of activation and energy consumption during the thin-layer drying of beriberi fruit (Berberidaceae). Energy Conversion and Management, 49: 2865-2871.

[36] Corzo, O., Bracho, N., Vasquez, A. and Pereira, A. 2008. Optimization of a thin layer drying process for coroba slices. Journal of Food Engineering, 85(2008), 372 - 380. 
[37] Boulemtafes-Boukadoum, A. and Benzaoui, A. 2011. Energy and exergy analysis of solar drying process of mint. Energy Procedia, 6(2001), 583 - 591.

[38] Rosen, M.A., Dincer, I. and Kanoglu, M. 2008. Role of exergy in increasing efficiency and sustainability and reducing environmental impact, Energy Policy, 36 (2008), 128 - 137.

\title{
PERFORMANSE HIBRIDNOG FOTOVOLTAŽNOG / TOPLOTNOG SUŠENJA U TOPLO-VLAŽNOM REGIONU NIGERIJE
}

\author{
Sampson Uzoma ${ }^{1}$, Nnaemeka Nwakuba ${ }^{2}$ and Kelechi Anyaoha ${ }^{1}$ \\ ${ }^{I}$ Department of Agricultural and Bio-Environmental Engineering, \\ Imo State Polytechnic, Umuagwo, Nigeria \\ ${ }^{2}$ Department of Agricultural and Bioresources Engineering, \\ Michael Okpara University of Agriculture, Umudike, Nigeria
}

Sažetak: Ovaj rad predstavlja studiju koja je sprovedena u cilju ispitivanja performansi hibridne fotonaponske/termičke sušare u toplo-vlažnom regionu UmuagvoOhaji, jugoistočni region Nigerije, kroz energetske i eks energijske analize: sušenje, električne i toplotne efikasnosti, koeficijent korišćenja energije i iskorišćenja energije, indikatori održivosti kao što su odnos energije otpada (VER), indeks održivosti (SI) i potencijal za poboljšanje (IP). Eksperimenti sušenja su sprovedeni na različitim temperaturama ulaznog vazduha $\left(50,60 \mathrm{i} 70^{\circ} \mathrm{C}\right)$, brzinama protoka vazduha $(1,14,2,29 \mathrm{i}$ $\left.3,43 \mathrm{~kg}^{-1}\right)$ i debljinama preseka $(10,15$ i $20 \mathrm{~mm})$ na $500 \mathrm{~g}$ serije šarži crvenog bibera tokom perioda izlaganju sunčevoj svetlosti.

Dobijeni rezultati pokazuju da ukupna i specifična potrošnja energije za sušenje serije rezanih uzoraka crvene paprike varira između 2,08 - 34,91 kJ i 7,04 - 62,76 $\mathrm{kJkg}^{-1}$, respektivno. Koeficijent korišćenja energije i iskorišćenosti energije tokom procesa sušenja kretao se od 195,75 do $3013,21 \mathrm{Js}^{-1}$ i 1,82 do $20,4 \%$, respektivno. Efikasnost energije i eks energije varira od 15,67 do $38,17 \%$ i $26 \%$ do $88 \%$, respektivno. Srednja efikasnost sušenja sistema kretala se od 7,12 do 40,27\%. Dobijene maksimalne električne i toplotne efikasnosti su od 23,86\% i 93,03\%. Dobijen je odnos energije energije od 0.0827 do 0.1579 , dok su SI i IP vrijednosti u rasponu $1.137 \leq \mathrm{SI} \leq 6.119 \mathrm{i}$ $0.198 \leq \mathrm{IP} \leq 0.583 \mathrm{kV}$, respektivno. Svakako postoji širok spektar poboljšanja u PV / T sistemu kao 12,1 do 18,4\% solarnog zračenja koje je potrošeno za sušenje.

Predložene su perspektive za poboljšanje i preporuke za dalje studije.

Ključne reči: energija, eksenergija, PV-T sistem, indikatori održivosti, termička konverzija

Prijavljen:

Submitted:

10.05.2019.

Ispravljen:

Revised:

15.05.2019.

Prihvaćen:

Accepted:

29.05.2019. 